\title{
$H$-Point Standard Addition Method for Simultaneous Determination of Zinc and Nickel in Micellar Media
}

\author{
RAJNI ROHILLA and USHA GUPTA* \\ Department of Chemistry, Punjabi University Patiala, Punjab, India \\ ushagupta_dr@yahoo.com
}

Received 5 June 2012 / Accepted 22 June 2012

\begin{abstract}
The $H$-point standard addition method (HPSAM) has been applied for simultaneous determination of $\mathrm{Zn}(\mathrm{II})$ and $\mathrm{Ni}(\mathrm{II})$ at trace levels, using Alizarin Red S (ARS) as chromogenic reagent. Both $\mathrm{Ni}(\mathrm{II})$ and $\mathrm{Zn}$ (II) form red colored complex with Alizarin red $\mathrm{S}$ at $\mathrm{pH} 7.0$ which are soluble in triton $\mathrm{x}-100 . \mathrm{Zn}(\mathrm{II})$ and $\mathrm{Ni}$ (II) have been determined simultaneously in the concentration range of $0.320-4.55 \mu \mathrm{g} / \mathrm{mL}$ and $0.293-4.676 \mu \mathrm{g} / \mathrm{mL}$ respectively with satisfactory accuracy and precision. The results of applying $H$-point standard addition method show that $\mathrm{Zn}$ (II) and $\mathrm{Ni}$ (II) ions can be determined simultaneously with concentration ratio of 15:1 and $1: 16$ of $\mathrm{Zn}$ (II) to $\mathrm{Ni}(\mathrm{II})$. This method is based on the difference in the absorbance of $\mathrm{Zn}$ (II) and $\mathrm{Ni}(\mathrm{II})$ - ARS complexes at pH 7.0 using different wavelength pairs.
\end{abstract}

Keywords: HPSAM, Zinc, Nickel, Simultaneous determination and triton x-100

\section{Introduction}

Zinc and nickel appear together in many real samples. Zinc compounds have biocidal activity because they precipitate and denature the bacterial proteins. For this reason it has been used in dermatology as an antiseptic and disinfectant agent in ophthalmic and mouthwash solutions and mineral-vitamin preparations. Nickel is the metal component of the enzyme urease and as such is considered to be essential to plants and some domestic animals. Nickel can cause allergic reactions and that certain nickel compounds may be carcinogenic

Several techniques such as x-ray fluorescence ${ }^{1}$, atomic fluorescence spectrometry ${ }^{2}$, polarography ${ }^{3}$, chromatography ${ }^{4}$, atomic absorption spectrometry ${ }^{5}$ etc. have been used for the simultaneous determination of these ions in different samples. Among the most widely used analytical methods are those based on the UV-Vis spectrophotometric techniques $^{6-13}$ due to the resulting experimental rapidity, simplicity and the wide application. However, the simultaneous determination of these ions by the use of the traditional spectrophotometric techniques is difficult because, generally, the absorption spectra overlap in a bright region and the superimposed curves are not suitable for quantitative evaluation. 
In 1988, Bosch - Reig and Campins - Falco ${ }^{14}$ delineated the fundamentals of $H$-point standard addition method (HPSAM), with which two species with mostly or even totally overlapping spectra can be determined. HPSAM is applied to work at two selected wavelengths where analytical signal due to one of the species (interferent) is constant and for another one (analyte) to be different as much as possible. By plotting the analytical signals versus added analytical concentration, two straight lines are obtained that have a common point $\mathrm{H}$ with coordinates $\left(\mathrm{C}_{\mathrm{H}}, \mathrm{A}_{\mathrm{H}}\right) ; \mathrm{C}_{\mathrm{H}}$ is the unknown analyte concentration and the $A_{H}$ is the analytical signal due to the interferent species.The HPSAM has been used, eliminating blank bias error due to the use of an absorbent blank ${ }^{15-16}$. HPSAM has also been applied to liquid chromatography ${ }^{17}$, analysis kinetic data analysis ${ }^{18-21}$ with an additional variant time and in metal speciation ${ }^{22-24}$.

Micelles possess a high potential for multicomponent analysis, which can be used as special reaction media because they alter the rate, equilibrium position, products and stereochemistry of many reactions. However, micelles also change the effective microenvironment around dissolved solutes and their physicochemical properties, such as absorptivity, equilibrium constant and spectral profile. Surfactants can interact with dye and/or the metal-dye complex as an individual molecule or aggregates. The addition of surfactant-active substances improves the selectivity and sensitivity of the metal determinations.

In the present work a very simple, sensitive, selective and low cost HPSAM for simultaneous determination of zinc and nickel using alizarin red S in triton x-100 micellar media is described. The method has been successfully applied for simultaneous determination of nickel and zinc in synthetic samples and spiked real water samples.

\section{Experimental}

A Shimadzu -1800 UV-Vis scanning spectrophotometer was used to record the absorbance spectra with $1.0-\mathrm{cm}$ path length quartz cell. Digital century pH-meter CP 901 with a combined glass electrode was used for $\mathrm{pH}$ measurements

\section{Reagents}

All chemicals used were of analytical reagent grade unless otherwise stated. Double distilled water was used throughout. A standard $\mathrm{Ni}(\mathrm{II})$ and $\mathrm{Zn}$ (II) solution were prepared in a standard flask. Working standard solutions were obtained by appropriate dilution of the stock solution. An aqueous solution of $(0.01 \% \mathrm{w} / \mathrm{v})$ Alizarin red S was prepared in double distilled water. A $(1.0 \% \mathrm{v} / \mathrm{v})$ triton $\mathrm{x}-100$ solution was prepared in hot distilled water. The $\mathrm{pH}$ of the working solution was adjusted at 7.0 using $0.5 \mathrm{M}$ ammonium hydroxide and $0.5 \mathrm{M}$ ammonium chloride buffers.

\section{Procedure}

Appropriate volumes of $\mathrm{Zn}(\mathrm{II})$ and $\mathrm{Ni}(\mathrm{II})$ standard solutions (Beer`s law was obeyed in the concentration range $0.320-4.55 \mu \mathrm{g} / \mathrm{mL}$ of Zinc and $0.293-4.676 \mu \mathrm{g} / \mathrm{mL}$ of nickel), $2.0 \mathrm{~mL}$ of $1.0 \%$ triton $\mathrm{x}-100,2.0 \mathrm{~mL}$ of buffer solution $(\mathrm{pH} 7.0), 1.0 \mathrm{~mL}$ of $0.01 \%$ alizarin red $\mathrm{S}$ solution were added into a $10.0 \mathrm{~mL}$ standard flask and volume was made up to the mark with double distilled water. A portion of the solution was transferred into a quartz cell and variations of absorbance were recorded for each sample. 


\section{Binary - HPSAM}

For the determination of $\mathrm{Zn}$ (II) and $\mathrm{Ni}(\mathrm{II})$ ions using HPSAM, the synthetic solution containing $\mathrm{Zn}(\mathrm{II})$ and $\mathrm{Ni}(\mathrm{II})$ ions at different concentration ratios were prepared with $1.0 \mathrm{~mL}$ of ARS solution, $2.0 \mathrm{~mL}$ of buffer solution $(\mathrm{pH} \mathrm{7.0)}$ and $2.0 \mathrm{~mL}$ of triton $\mathrm{x}-1001.0 \%$ in $10-\mathrm{mL}$ volumetric flasks. Absorbance of solution was measured at $564 \mathrm{~nm}$ and $504 \mathrm{~nm}$ (when standard solution of $\mathrm{Ni}(\mathrm{II})$ was added) or 592 and $510 \mathrm{~nm}$ (when standard solution of $\mathrm{Zn}$ (II) was added) against a reagent blank and graphs of absorbance $v s$. concentration were plotted. $\mathrm{C}_{\mathrm{H}}$ and $\mathrm{A}_{\mathrm{H}}$ were obtained from the point of intersection of the two derived straight lines.

\section{Results and Discussion}

\section{Absorption spectra}

The absorption spectra for $\mathrm{Zn}(\mathrm{II})$ and $\mathrm{Ni}$ (II) complexes with ARS against blank solution are shown in Figure 1. As Figure 1 shows, the spectra of the complexes overlap with each other, and therefore each compound interferes in the spectrophotometric determination of the other. But simultaneous determination of $\mathrm{Zn}$ (II) and $\mathrm{Ni}$ (II) is possible by using HPSAM.

\section{Optimization of various parameters}

To take full advantage of the procedure, the reagent concentrations and reaction conditions must be optimised. These parameters were optimised by setting all parameters to be constant and optimizing one each time.

\section{Effect of $p H$}

The effect of $\mathrm{pH}$ on the spectra of a constant concentration of each complex was investigated in the range of 3.5-9.5. The results from Figure 2 showed that the $\mathrm{pH}$ of 7.0 gives the highest sensitivity for determination of $\mathrm{Zn}$ (II) and $\mathrm{Ni}$ (II) respectively. For both cations $\mathrm{pH} 7.0$ was selected as the suitable one for simultaneous analysis of $\mathrm{Zn}$ (II) and $\mathrm{Ni}(\mathrm{II})$.

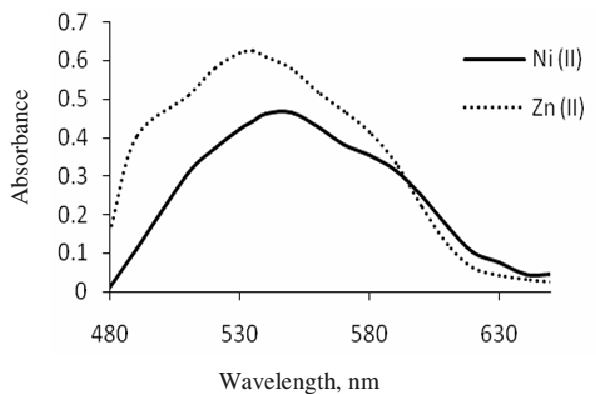

Figure 1. Absorption spectra of $\mathrm{Zn}(\mathrm{II})$ and $\mathrm{Ni}(\mathrm{II})$ with $1.0 \mathrm{~mL}$ ARS $(0.01 \%)$ solution and $2.0 \mathrm{~mL}$ triton $\mathrm{x}-100(1 \%)$ at $\mathrm{pH} 7.0$

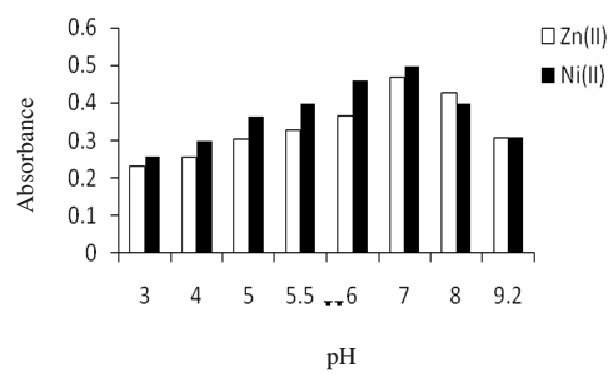

Figure 2. Effect of $\mathrm{pH}$ on the change in the absorbance of $\mathrm{Zn}(\mathrm{II})$ and $\mathrm{Ni}(\mathrm{II})$-ARS complexes

\section{Effect of nature of the surfactant}

Various surfactants such as triton $\mathrm{x}-100$, Tween-20, Tween-80, cetylpyridiniumbromide (CPB), cetyltrimethylammonium bromide (CTAB) and sodium lauryl sulphate (SLS) were tried as solubilizing agents. Both for $\mathrm{Zn}(\mathrm{II})$-ARS and Ni(II) -ARS complex absorbance was maximum with triton $\mathrm{x}-100$ as shown in Figure 3. So, for simultaneous determination of $\mathrm{Zn}(\mathrm{II})$ and $\mathrm{Ni}(\mathrm{II}), 2.0 \mathrm{~mL}$ of $1.0 \%$ triton $\mathrm{x}-100$ was selected as the working micellizing agent for further studies. 


\section{Effect of Alizarin red $S$ (ARS) concentration}

Effect of different amounts of ARS on the absorbance of Zn(II)-ARS and Ni(II) -ARS complexes was studied. The maximum absorbance in both the cases was observed when $0.5 \mathrm{~mL}$ and $0.5 \mathrm{~mL}$ of $0.01 \%$ ARS was used for individual calibration of $\mathrm{Zn}$ (II) and $\mathrm{Ni}$ (II) as shown in Figure 4. It was expected that increasing ARS concentration causes an increase in absorbance because increase in ARS concentration caused an increase in $\mathrm{Zn}$ (II) and $\mathrm{Ni}$ (II) complexes concentration. At higher concentrations of ARS, the concentration of complex did not change significantly but the concentration of uncomplexed ARS increased significantly. Therefore, much probably decrease in absorbance at higher concentrations of ARS. To ensure the complete complexation for simultaneous determination of $\mathrm{Zn}$ (II) and $\mathrm{Ni}(\mathrm{II}), 1.0 \mathrm{~mL}$ of $0.01 \%$ ARS was selected as the optimum .

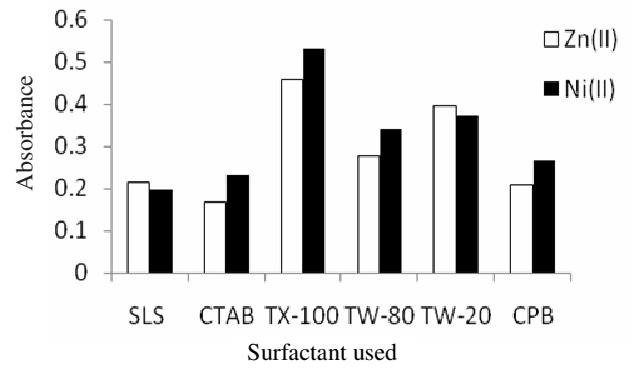

Figure 3. Effect of surfactants on complex formation of $\mathrm{Zn}(\mathrm{II})$ and $\mathrm{Ni}(\mathrm{II})-\mathrm{ARS}$

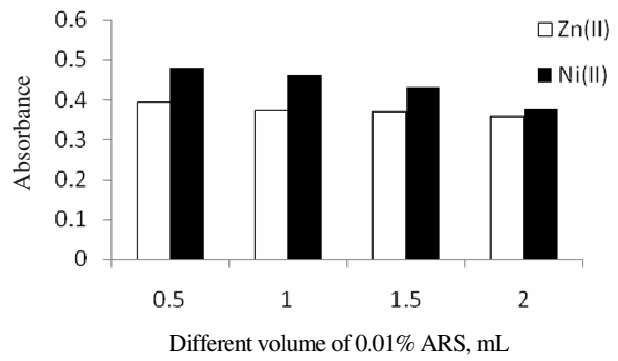

Figure 4. Effect of reagent concentration on the change in the absorbance of $\mathrm{Zn}(\mathrm{II})$ and $\mathrm{Ni}(\mathrm{II})-\mathrm{ARS}$ complexes

\section{Applying H-point standard addition method (HPSAM)}

Either $\mathrm{Zn}(\mathrm{II})$ or $\mathrm{Ni}(\mathrm{II})$ can be selected as analyte when applying binary-HPSAM. When $\mathrm{Zn}$ (II) was selected as an analyte, many pairs of wavelengths showing the same absorbance for $\mathrm{Ni}(\mathrm{II})$-ARS complex were possible. In the selection of one pair of wavelengths for obtaining good accuracy, the absorbance differences at the two selected wavelengths for $\mathrm{Zn}$ (II)-ARS complex must be as large as possible. Based on the absorption spectra of $\mathrm{Zn}(\mathrm{II})$ or $\mathrm{Ni}(\mathrm{II})$ complexes, one of the best pair of wavelengths was $592.0 \mathrm{~nm}$ and $510.0 \mathrm{~nm}$ when standard solution of $\mathrm{Zn}(\mathrm{II})$ were added i.e. $\mathrm{Zn}$ (II) was selected as analyte. Similarly, best pair of wavelengths for applying binary -HPSAM was 564.0 and 504.0 when $\mathrm{Ni}(\mathrm{II})$ was selected as an analyte. $\mathrm{C}_{\mathrm{H}}$ and $\mathrm{A}_{\mathrm{H}}$ were obtained from the point of intersection of the two derived straight lines in the $H$-point graphs of absorbance versus analyte concentration where $-\mathrm{C}_{\mathrm{H}}$ was the concentration of analyte and $\mathrm{A}_{\mathrm{H}}$ the analytical signal due to interferent spices.

Several experiments for evaluating HPSAM on the determination of $\mathrm{Zn}$ (II) and Ni (II) in a series of samples containing fixed amounts of $\mathrm{Zn}$ (II) with different amounts of $\mathrm{Ni}$ (II) (Figure 5) or fixed amounts of $\mathrm{Ni}(\mathrm{II})$ with different amounts of $\mathrm{Zn}$ (II) (Figure 6) were carried out by adding Zn(II) standard solutions. The applicability of HPSAM was also tested for determination of $\mathrm{Ni}(\mathrm{II})$ and $\mathrm{Zn}(\mathrm{II})$ in a series of samples containing fixed amounts of $\mathrm{Ni}$ (II) together with different amounts of $\mathrm{Zn}$ (II) (Figure 7) or fixed amounts of $\mathrm{Zn}$ (II) together with different amounts of $\mathrm{Ni}$ (II) (Figure 8) were carried out by adding $\mathrm{Pb}(\mathrm{II})$ standard solutions. The results show that $\mathrm{Zn}$ (II) and $\mathrm{Ni}$ (II) contents in the samples could be determined accurately. 


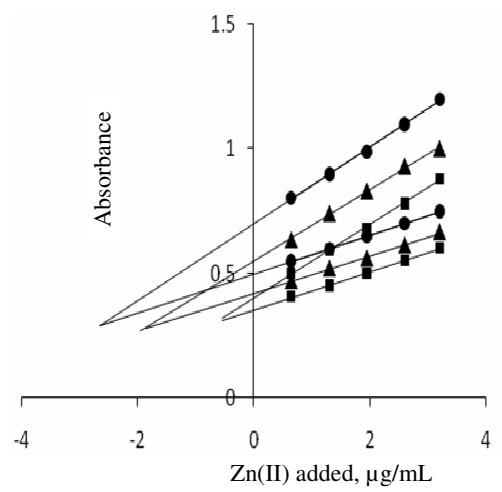

Figure 5. Plot of $H$-point standard addition method for simultaneous determination of fixed amounts of $\mathrm{Ni}$ (II) and different amounts of $\mathrm{Zn}(\mathrm{II})$. [Condition: $p H$ 7.0, $2.0 \mathrm{~mL}$ of $1.0 \%$ triton $x-100,2.0 \mathrm{~mL}$ of $0.01 \%$ alizarin red $S$ and $0.586 \mu \mathrm{g} / \mathrm{mL} \mathrm{Ni}(\mathrm{II})$ and different concentration of $Z n(I I)$, when different amounts of standard $\mathrm{Zn}(\mathrm{II})$ solutions are added]

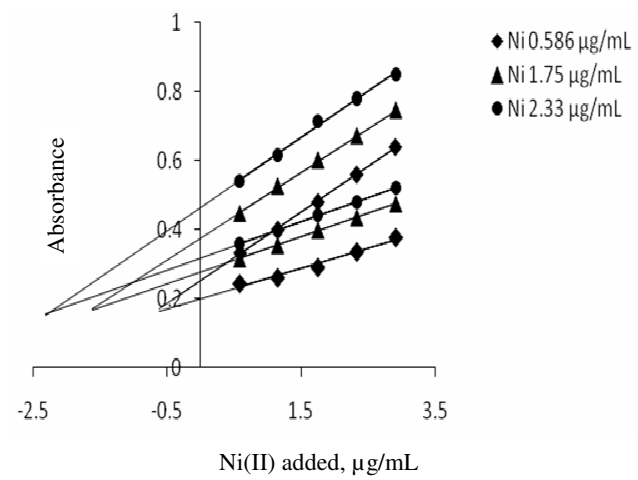

Figure 7. Plot of $H$-point standard addition method for simultaneous determination of fixed amounts of $\mathrm{Zn}$ (II) and different amounts of $\mathrm{Ni}(\mathrm{II})$. [Condition: $p H$ 7.0, $2.0 \mathrm{~mL}$ of $1.0 \%$ triton $x-100,2.0 \mathrm{~mL}$ of $0.01 \%$ alizarin red $S$ and $0.656 \mu \mathrm{g} / \mathrm{mL} \mathrm{Zn}(\mathrm{II})$ and different concentration of $\mathrm{Ni}(\mathrm{II})$, when different amounts of standard Ni(II) solutions are added]

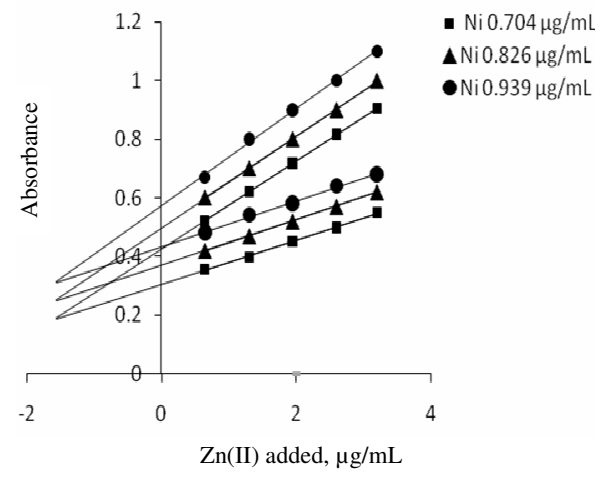

Figure 6. Plot of H-point standard addition method for simultaneous determination of fixed amounts of $\mathrm{Zn}(\mathrm{II})$ and different amounts of $\mathrm{Ni}(\mathrm{II})$. [Condition: $p H$ 7.0, $2.0 \mathrm{~mL}$ of $1.0 \%$ triton $x-100,2.0 \mathrm{~mL}$ of $0.01 \%$ Alizarin red $S$ and $1.25 \mu \mathrm{g} / \mathrm{mL} \mathrm{Zn}(\mathrm{II})$ and different concentration of $\mathrm{Ni}(\mathrm{II})$, when different amounts of standard $\mathrm{Zn}(\mathrm{II})$ solutions are added]

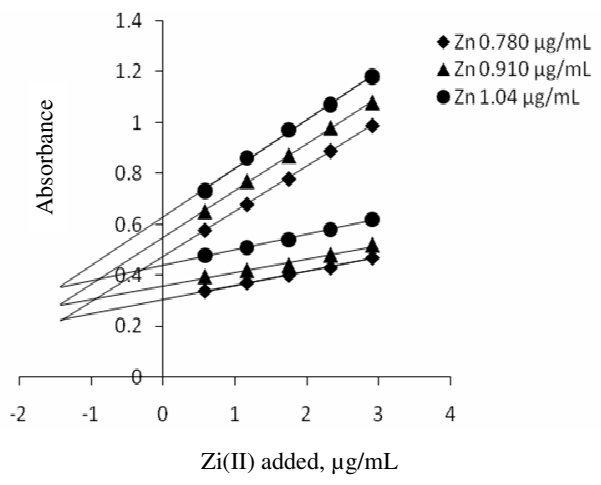

Figure 8. Plot of $H$-point standard addition method for simultaneous determination of fixed amounts of $\mathrm{Ni}$ (II) and different amounts of $\mathrm{Zn}$ (II). [Condition: $p H$ 7.0, $2.0 \mathrm{~mL}$ of $1.0 \%$ Triton $x-100,2.0 \mathrm{~mL}$ of $0.01 \%$ alizarin red $S$ and $1.30 \mu \mathrm{g} / \mathrm{mL} \mathrm{Ni}$ (II) and different concentration of $\mathrm{Zn}(I I)$, when different amounts of standard Ni(II) solutions are added]

\section{Reproducibility of the HPSAM}

Under optimum conditions described above, simultaneous determination of $\mathrm{Zn}$ (II) and $\mathrm{Ni}$ (II) were made using HPSAM. To investigate the reproducibility of the method, four replicate 
measurements of the $\mathrm{Zn}(\mathrm{II})$ and $\mathrm{Ni}(\mathrm{II})$ were performed (Table 1). The concentrations of both species were obtained from $\mathrm{C}_{\mathrm{H}}$ values. The relative standard deviation (R.S.D.) for determination of $\mathrm{Zn}$ (II) and $\mathrm{Ni}$ (II) were obtained as 0.764 and $0.1493 \%$, respectively.

Table 1. Results of several experiments for the analysis of $\mathrm{Zn}(\mathrm{II})$ and $\mathrm{Ni}(\mathrm{II})$ mixtures in different concentration by HPSAM

\begin{tabular}{cccccccc}
\hline \multirow{2}{*}{ A-C Equation } & \multicolumn{9}{c}{$\mathrm{r}^{2} \mathrm{Present} \mu \mathrm{g} / \mathrm{mL}$} & \multicolumn{2}{c}{ Found, $\mu \mathrm{g} / \mathrm{mL}$} & \multicolumn{2}{c}{ (\%Recovery) } \\
& & $\mathrm{Ni}$ & $\mathrm{Zn}$ & $\mathrm{Ni}$ & $\mathrm{Zn}$ & $\mathrm{Ni}$ & $\mathrm{Zn}$ \\
\hline $\mathrm{A}_{564}=0.213 \mathrm{C}_{\mathrm{i}}+0.774$ & 0.9985 & 0.586 & 1.43 & 0.561 & 1.42 & 95.73 & 99.30 \\
$\mathrm{~A}_{504}=0.034 \mathrm{C}_{\mathrm{i}}+0.669$ & 0.9994 & & & & & & \\
$\mathrm{~A}_{564}=0.369 \mathrm{C}_{\mathrm{i}}+0.523$ & 0.9998 & 1.170 & 1.43 & 1.172 & 1.39 & 100.17 & 97.20 \\
$\mathrm{~A}_{504}=0.225 \mathrm{C}_{\mathrm{i}}+0.354$ & 0.9996 & & & & & & \\
$\mathrm{~A}_{564}=0.413 \mathrm{C}_{\mathrm{i}}+0.526$ & 0.9999 & 0.708 & 1.569 & 0.704 & 1.559 & 99.43 & 99.36 \\
$\mathrm{~A}_{504}=0.230 \mathrm{C}_{\mathrm{i}}+0.397$ & 0.9988 & & & & & & \\
$\mathrm{~A}_{564}=0.395 \mathrm{C}_{\mathrm{i}}+0.558$ & 0.9989 & 0.826 & 1.569 & 0.839 & 1.561 & 101.57 & 99.49 \\
$\mathrm{~A}_{504}=0.221 \mathrm{C}_{\mathrm{i}}+0.412$ & 0.9986 & & & & & & \\
$\mathrm{~A}_{592}=0.195 \mathrm{C}_{\mathrm{i}}+0.251$ & 0.9985 & 1.29 & 0.650 & 1.31 & 0.653 & 100.46 & 101.55 \\
$\mathrm{~A}_{510}=0.097 \mathrm{C}_{\mathrm{i}}+0.187$ & 0.9996 & & & & & & \\
$\mathrm{~A}_{592}=0.189 \mathrm{C}_{\mathrm{i}}+0.267$ & 0.9989 & 1.29 & 1.307 & 1.27 & 1.304 & 98.44 & 99.77 \\
$\mathrm{~A}_{510}=0.107 \mathrm{C}_{\mathrm{i}}+0.160$ & 0.9998 & & & & & & \\
$\mathrm{~A}_{592}=0.117 \mathrm{C}_{\mathrm{i}}+0.240$ & 0.9999 & 1.40 & 1.430 & 1.43 & 1.470 & 102.14 & 102.79 \\
$\mathrm{~A}_{510}=0.073 \mathrm{C}_{\mathrm{i}}+0.175$ & 0.9998 & & & & & & \\
$\mathrm{~A}_{592}=0.091 \mathrm{C}_{\mathrm{i}}+0.318$ & 0.9985 & 1.40 & 1.560 & 1.38 & 1.580 & 101.28 & 98.57 \\
$\mathrm{~A}_{510}=0.043 \mathrm{C}_{\mathrm{i}}+0.242$ & 0.9984 & & & & & & \\
\hline
\end{tabular}

Precision and accuracy of the HPSAM

In order to obtain accuracy of the method several synthetic mixtures with different concentration ratios of $\mathrm{Zn}(\mathrm{II})$ and $\mathrm{Ni}(\mathrm{II})$ were analyzed using the proposed HPSAM. The results are given in (Table 2). As can be seen in (Tables 1 and 2), the precision and accuracy of the method are both satisfactory.

Table 2. Results of four replicate experiments for the analysis of $\mathrm{Zn}(\mathrm{II})$ and $\mathrm{Ni}(\mathrm{II})$ mixtures

\begin{tabular}{|c|c|c|c|c|}
\hline \multirow[t]{2}{*}{ A-C Equation } & \multicolumn{2}{|c|}{ Present, $\mu \mathrm{g} / \mathrm{mL}$} & \multicolumn{2}{|c|}{ Found, $\mu \mathrm{g} / \mathrm{mL}$} \\
\hline & $\mathrm{Ni}$ & $\mathrm{Zn}$ & $\mathrm{Ni}$ & $\mathrm{Zn}$ \\
\hline $\mathrm{A}_{564}=0.197 \mathrm{C}_{\mathrm{i}}+0.250$ & 0.650 & 0.950 & 0.653 & 0.948 \\
\hline $\mathrm{A}_{504}=0.099 \mathrm{C}_{\mathrm{i}}+0.186$ & & & & \\
\hline $\mathrm{A}_{564}=0.191 C_{\mathrm{i}}+0.252$ & 0.650 & 0.950 & 0.645 & 0.949 \\
\hline $\mathrm{A}_{504}=0.095 \mathrm{C}_{\mathrm{i}}+0.190$ & & & & \\
\hline $\mathrm{A}_{564}=0.195 \mathrm{C}_{\mathrm{i}}+0.248$ & 0.650 & 0.950 & 0.642 & 0.951 \\
\hline $\mathrm{A}_{504}=0.097 \mathrm{C}_{\mathrm{i}}+0.185$ & & & & \\
\hline $\mathrm{A}_{564}=0.194 \mathrm{C}_{\mathrm{i}}+0.246$ & 0.650 & 0.950 & 0.645 & 0.948 \\
\hline $\mathrm{A}_{504}=0.098 \mathrm{C}_{\mathrm{i}}+0.184$ & & & & \\
\hline Mean & & & 0.645 & 0.949 \\
\hline $\mathrm{RSD}, \%$ & & & 0.764 & 0.149 \\
\hline LOD & & & 0.014 & 0.004 \\
\hline LOQ & & & 0.049 & 0.014 \\
\hline
\end{tabular}




\section{Interference analysis}

The effect of various diverse ions on the absorbance of a solution containing $1.0 \mu \mathrm{g} / \mathrm{mL}$ each of $\mathrm{Zn}(\mathrm{II})$ and $\mathrm{Ni}(\mathrm{II})$ was studied. An ion was considered to interfere when its presence produced a variation in the absorbance of the sample greater than 5\%. Among the anions examined $\mathrm{F}^{-}, \mathrm{I}^{-}, \mathrm{Br}^{-}, \mathrm{Cl}^{-}, \mathrm{CO}_{3}{ }^{2-}, \mathrm{SO}_{3}{ }^{2-}, \mathrm{SO}_{4}{ }^{2-}, \mathrm{NO}_{3}^{-}, \mathrm{IO}_{3}{ }^{-}, \mathrm{NO}_{2}^{-}, \mathrm{S}_{2} \mathrm{O}_{3}{ }^{2-}$ and $\mathrm{CH}_{3} \mathrm{COO}^{-}$did not interfere at concentrations 1000 times higher than those of the analytes but ethylenediamine tetraacetate ion, oxalate ions interfered strongly. Among the cations $\mathrm{Hg}^{2+}, \mathrm{Cd}^{2+}$ and $\mathrm{Cu}^{2+}$ were masked with $1.0 \mathrm{~mL}$ of $5 \%$ sodium fluoride solution. $\mathrm{Bi}^{2+}$ was masked with $2.0 \mathrm{~mL}$ of $1 \mathrm{M}$ sodium citrate solution.

\section{Application}

HPSAM was applied to the determination of $\mathrm{Ni}(\mathrm{II})$ and $\mathrm{Zn}$ (II) in several real matrix samples. For this purpose, diverse spiked water samples were analysed. The results of analysis are shown in Table 3. The good agreement between these results and known values indicates the successful applicability of the proposed method for simultaneous determination of $\mathrm{Ni}(\mathrm{II})$ and $\mathrm{Zn}(\mathrm{II})$.

Table 3. Determination of Ni(II) and Zn(II) mixtures in different water samples by BinaryHPSAM

\begin{tabular}{ccccc}
\hline Water sample & \multicolumn{2}{c}{ Spiked, $\mu \mathrm{g} / \mathrm{mL}$} & \multicolumn{2}{c}{ Found, $\mu \mathrm{g} / \mathrm{mL}$} \\
\hline & $\mathrm{Zn}(\mathrm{II})$ & $\mathrm{Ni}(\mathrm{II})$ & $\mathrm{Zn}(\mathrm{II})$ & $\mathrm{Ni}(\mathrm{II})$ \\
\hline Yamuna River $^{*}$ & 0.455 & 0.670 & 0.449 & 0.676 \\
water $^{*}$ & 1.00 & 1.00 & 1.07 & 1.10 \\
Ganga River $^{* * *}$ & 0.355 & 0.655 & 0.357 & 0.656 \\
Water & 0.65 & 1.00 & 0.70 & 1.05 \\
Industrial waste $^{* * * *}$ & 0.350 & 0.380 & 0.352 & 0.376 \\
water & & & & \\
\hline
\end{tabular}

${ }^{*}$ Collected from Yamuna Nagar. ${ }^{* *}$ Collected from Haridwar, ${ }^{* * *}$ Collected from NAHAR industries Ltd.; Bhanut

\section{Conclusion}

The proposed method offers significant advantages over conventional methods because of its speed and ease of operation. This method works without the need of preconcentration or extraction steps. Thus, the inherent errors involved in these time-consuming steps using toxic and carcinogenic organic solvents are avoided and determination in aqueous phase using micellar system makes the procedure eco-friendly. The proposed spectrophotometric method has a low detection limit which enhances its sensitivity. Moreover, low cost of the instrument, easy handling and almost no maintenance have made spectrophotometry still a popular technique.

\section{References}

1. Jiang Z T, Yu J C and Liu H Y, Anal Sci., 2005, 21(7), 851.

2. Sun H W and Suo R, Anal Chim Acta., 2004, 509, 71-76.

3. Reyes-Salas E O, Dosal-Gomez M A, Barcelo-Quintal M H, Manzanilla-Cano J A, Anal Lett., 2002, 35, 123-133.

4. Hu Q F, Wu X H, Yang G Y, Huang Z J, Yin J Y, J Chin Chem Soc., 2005, 52, 277.

5. Bohrer D, Cicero do Nascimento P, Guterres M, Trevisan M and Seibert E, Analyst, 1999, 124(9), 1345. 
6. Ho W H, Chen C L and Chen H R, J Chin Chem Soc., 1995, 42(1), 51.

7. Hu N-L, Gao H-W, Zhang B and Zhan G-Q, J Chin Chem Soc., 2005, 52, 1145-1152.

8. Ghasemi J and Abbas B, J Chin Chem Soc., 2005, 52, 1123.

9. Madrakian T, Afkhami A, Borazjani M and Bahram M, Spectrochim Acta A, 2005, 61(2994), 2988.

10. Ghasemi J, Ahmadi S and Torkestani K, Anal Chim Acta, 2003, 487, 181-188.

11. Ghasemi J, Shahabadi N and Seraji H R, Anal Chim Acta, 2004, 510, 121.

12. Grabaric Z, Lazarevic Z and Koprivanac N, Analyst, 1994, 119, 1099.

13. Garcia Rodriguez M, Garcia de Torres A, Cano Pavon J M and Bosch Ojeda C, Talanta, 1998, 47, 463.

14. Bosch-Reig F and Campins-Falco P, Analyst, 1988, 113, 1011-1016.

15. Bosch-Reig F, Campins-Falco P and Verdu- Andres J, Anal Chim Acta, 1992, 270, 253-265.

16. Bosch-Reig F, Campins-Falco P, Verdu- Andres J and Molins-Legua C, Talanta, 1994, 41, 39-52.

17. Blasco-Gomez F, Campins-Falco P, Bosch- Reig F and Molins-Legua C, Anal Chem., 2000, 72(11), 2559-2565.

18. Bosch-Reig F, Campins-Falco P, Sevillano- Cabez A, Herraez-Hernandez R and Molins-Legua C, Anal Chem., 1991, 63, 2424.

19. Safavi A, Abdollahi H and Hormozi Nezhad M R, Talanta, 2002, 56(4), 699-704 .

20. Safavi A, Abdollahi H, Sedaghatpour F and Zeinali S, Anal Chim Acta, 2000, 409, 275-282.

21. Safavi A, Abdollahi H, Sedaghatpour F and Hormozi Nezhad M R, Talanta, 2003, 59(1), 147-153.

22. Safavi A and Abdollahi H, Microchem J., 1999, 63,211.

23. Safavi A and Abdollahi H, Anal Lett., 2001, 31, 2871.

24. Zolgharnein J, Abdollahi H and Jafarifar D, Talanta, 2002, 57, 1067. 